\title{
映像におけるリアリティの起源
}

\section{The Origin of Reality in Image}

\section{佐々木和彦 SASAKI Kazuhiko}

This paper is a logical analysis of reality in images. I use the term "reality" to mean the force that compels us to repeatedly experience an image and at the same time attracts our visual desire. There are two purposes here: (1) to reveal the origin of "reality" in images, and (2) to consider what kind of desire could be generated by stimulating our sensibility. Regarding the concrete analysis, I first reveal characteristics of the human sense of sight. Secondly, I analyze the features of images and the human visual desire using Barthes's concept of "the gaze" and Lacan's concept of "objet petit a". Finally, I present that the origin of "reality" in images consists in "the gaze" as "objet petit a".

\section{1.はじめに}

本稿のテーマは、映像がそれを見る者に対して与えるリアリティの効果は、一体映像の どのような特性に由来するものなのかということを探求することである。但し、われわれ がここで映像におけるリアリティと名付けているものは、例えば、「写真は実在する事物 あるいは光景を複製（再現表象）するから、われわれにとって現実的であるのだ」という 事実確認的なレヴェルの記述に還元し得るような映像の迫真的な現実感ではない。何故な らば、映像におけるリアリティが、再現のフィデリティに還元し得る性質のものであると するならば、われわれにとって映像の地位は、単に様々な事象を再現し伝達する透明な媒 体にすぎなくなるからである。しかし、マクルーハンがそのメディア論において「メディ アはメッセージである」[McLuhan 1964:訳 7]というテーゼを通して主張したように、情 報伝達の過程ではその情報を運ぶメディアの形式が決定的な役割を果たしているのなら ば、また実際に種々のメディアを媒介变数として社会的な現実が構成され変換されてゆき、 われわれの関係の様式が常にメディアという強力な変数によって規定されているとするな らば、われわれは映像によって再現された内容ではなく、その再現の形式それ自体に注意 を向けなければならない。それ故に、われわれが映像のリアリティに関して問うべき事柄 は、一つには、「映像は真実をどれほど忠実に再現しているか」という映像の情報伝達的 側面に関わる問題が挙げられるだろう。しかし、それに加えて、「映像はいかなる真実を われわれに語りかけているのか」という映像とそれを見るわれわれ主体との関係の中から 見えてくる真実もまた問われなければならないのである。

確かに光学装置によって可能となった表象機能は、それ以前のどの表象システムとも異 なるそれ固有の特質を備えることによって、その表象の再現性においてある絶対的な客観 性のレヴェルを獲得し得たのは事実である。その結果として、映像の客観性に対する素朴 な認識的信頼が自明性を獲得し、映像が伝える内容は真実であるという社会的な了解が成 立していくという、マス・コミュニケーション過程においては危惧すべき問題が生じる可 
能性もあるだろう。しかし、そうした映像の客観性に対するナイーブな反応及びその効果 に対しては、様々なコンテクストから、そこに内包されているイデオロギー性を巡って倫 理的批判が提出され、それを支える歴史的・社会的・文化的な基礎条件を見出すべく理論 的あるいは実証的な研究も積み重ねられてきている。但し、そもそもそうした社会科学を 背景としたマス・コミュニケーション理論が提出され得るのは、映像がいかに現実の光景 を忠実に再現するメディアであろうと、それはあくまで一つの表象に過ぎないという映像 の存立条件を、われわれが弁えているからであろう。そうであるならば、必然的に浮上し てくる次のような問題が解決されなければならない。即ち、映像を単なる再現表象である と知りながら、尚且つそれに対してわれわれの知覚的「転移」という現象が発生するとす るならば、そのような事態を可能にする要因は一体何処にあるのか、という問題である。 寧ろ、一定の理解力と自己抑制力を備えた批判的な観客が映像に対していかに懐疑的且つ 現実主義的態度で接しようとも、そこに発生する知覚的転移の由来を検討することこそ、 われわれの映像に対する認識的な自明性を問い直し、われわれの無意識の欲望に対して映 像が担っている地位を分析し得るのではないか。そして、われわれが映像におけるリアリ ティに関して真に分析的であると考える点も、そうしたわれわれに対して繰り返し映像体 験を反復するように強いる映像的効力に他ならない。

しかし、映像に対するわれわれの知覚的転移の由来を、映像それ自体の特性から理論的 に分析するという試みは、必ずしも社会学的概念に基づいて体系的に展開されてきたとは 言えない。その原因は、社会学の理論に内在する問題であるというよりは、バンヴェニス トが言うように、そもそも「ほかのコミュニケーションの体系は、書かれたものでも、身 ぶりでも、視覚的なものでも、すべてそこ（言語）から誘導されたもので、それを前提と している」[Benveniste 1966:訳 31]という事情に起因している。つまり、言語が他のコミ ユニケーション体系を解釈し得る唯一の手段であるならば、言語は映像をどのように記述 し得るのか、という映像それ自体を分析の対象とする理論研究に伴う方法論上の問題であ る。そうした映像研究が抱える困難に対して、映像の研究に記号学の方法論を適用する試 みは、映像を一つの記号体系として捉えることによって、映像の形式的分析を可能にし、 映像の記号としての構造とその意味作用の過程をより厳密に説明する原理を手にしたと言 える。しかし、より根本的な原因は、われわれの経験一般が言語という分節的構造に支え られて初めて可能になるのならば、われわれが映像を見るという視覚的体験はいかなる経 験の水準に位置付けられるのか、というわれわれの経験の条件に起因する認識論上の問題 である。そこでわれわれは以下において、まずわれわれ人間の視覚の在り方を検討した上 で、映像に対するわれわれの知覚的転移を促す力は、映像が持つどのような内在的特性に 由来し、われわれの無意識の欲望のどのような在り方に起源を持つのか、ということを考 察していく。尚、われわれが本稿において考察の対象とする映像とは、化学光学的映像、 即ちキャメラのレンズから取り込まれた事物の反射光を、銀を使った感光材料に露光した 上で、それを化学的に現像処理した結果得られる、化学光学的装置によって表象された実 在する事物の視覚的再現像としての映像である。そのような具体的対象の視覚的模像とし ての映像、その中でも主に写真と映画に議論を限定して分析を進めていく。 


\section{2.人間の視覚と映像の地位について}

それでは、われわれが映像のうちに、単にそこに再現表象されている内容を見ているだ けではなく、われわれの知覚的転移を誘うような部分、即ち無意識の欲望の対象となり得 る成分を見ているとするならば、それは一体映像のいかなる側面を指すのであろうか。こ うした問いに応えるために、われわれはまず、人間の視覚の在り方を確認しておく。

人間の視覚の特質は次の三点に求められるであろう。第一の特質は視覚の「中枢性」で ある。前田によるならば、人間の視覚は、大脳を含む神経系を核とする身体の生理的な機 構の内部にプログラムされている行動における有用性を前提にした外界からの刺激に対す る反応のプロセスに基づいて遂行されるようになっているという[前田1996]。このような 中枢神経系の機能を前提とする人間の視覚の在り方から導き出せることは、人間の視覚的 営為はすべてその中枢性に基づいて作動し、その視覚が捉える光景は象徴的意味作用の体 系によってゲシュタルト化された全体として構成されているということである。つまり、 「われわれは対象／視野の切り取りを論理用法のタイプの違いに従って行なう」[岡崎 1995:97]が故に、視覚における論理用法が異なる対象を同時に見ることはできず、従って、 中枢的な視覚の働きは、その視線を誘導する視覚の焦点となるべき行動の有用性に基づい て選択された対象を、その都度設定し追跡するように機能するようになっているというこ とである。

第二の特質は、われわれの視覚体験を支えている不可避の認識論的構造である。それを 非常に簡略化して言えば、「ノエシス的作用」と「ノエマ的表象」とから成っていると言 えるだろう [木村 1988:24]。ノエシス的作用とは、視覚の作用（知覚活動）そのもの、即 ち対象を見る一瞬一瞬の現在においてノエマ的表象を産出し続けながら、それ自体は志向 的意識によっては把握-対象化することは原理上不可能な、視覚の実践的な働きそのもの である。ノエマ的表象とは、知覚の実践的な働きが意識に送り込んだ表象であり、われわ れの体験における一瞬一瞬の現在に脈絡を与え、経験の全体的な縓りを構成するために必 要とされる時間的空間的に分節化された表象である。換言するならば、視覚体験の整合性 が破綻することなく成立し得る条件は、われわれの視覚のノエシス的作用が断続的に受容 する感覚与件が分節的象徵体系に回付された上で論理的に処理され、ノエマ的表象として 主体の内部で継起的に再配置-統合（再自己固有化、超越論的統覚）される可能性にかか っているということである。そして、それを遂行するのは、カントによるならば、予め主 体の中にインストールされている認識論的構造、即ち直観の形式とア・プリオリなカテゴ リーという知覚それ自体に組み込まれている主観的な形式であるとされている $[\mathrm{Kant}$ 1787]。

第三の特質は、視覚の自己言及的構造である。ウィトゲンシュタインによるならば、わ れわれ主体の「視野における何物からも、それが眼によって見られていることは推論され えない」[Wittgenstein 1921:訳 97]という。それは、言い換えるならば、われわれの視覚の ノエシス的活動が捉え意識に送り込まれたノエマ的表象の中には、われわれが確かにそれ らの対象を目撃したのだという客観的な証拠となり得るものは何一つないということであ る。こうした主張の論拠は何処にあるのか。それは、われわれの視覚が捉えた感覚与件の 真偽について判断を下す審級が、当のわれわれ自身に他ならないという自己言及的構造に 在る。そうであるならば、われわれの視覚によって捉えられた感覚与件は、その現実性に 
関して主観的な判断以外に何の根拠も持っていないということになるだろう。しかし、そ うした視覚的経験の現実性を支える客観的根拠の不在は、われわれが自らの生の内部にい る限り、客観的且つ普遍的視点から世界を見ることはできないという、視覚の構造上「乗 り越えがたい生きられる独我論」[Merleau-Ponty 1945:訳(2) 225]の内部に閉じ込められて いる以上、不可避の帰結なのである。

以上挙げてきた三つの特質は、われわれ人間の視覚がその構造上不可避的に内包せざる を得ない認識論上の本性であるが、人間の視覚がそうした知覚的条件に支えられているな らば、われわれが見ている世界が確かに存在するということ、即ち世界それ自体の実在性 とそれを見ているわれわれ自身の知覚の真実性は、形式論理的にはそれを証明し得ない、 従ってそれが幻影であることを否定し得ない、極めて疑わしいものとなるであろう。

それでは、このように極めて脆弱な基盤の上に立っていると言えるわれわれ人間の視覚 にとって、映像はいかなる地位にあるのだろうか。それは、われわれの眼が捉えた世界が、 人間の視覚の本性に由来してその物質的及び心的現実性に関して何の確証も与えられな い、あくまで認識論的な「現象」としてのみその姿を開示していたのと同様に、単なる 「表象」として受容されるばかりなのであろうか。そうであるならば、われわれの視覚に 対する映像の地位は、次の二つのレヴェルに位置付けられる他ない。即ち、情報伝達と象 徵表現のレヴェルである。第一の情報伝達のレヴェルとは、コミュニケーションのレヴェ ルであり、化学光学的装置によって再現されている対象の視覚的情報に関する共同主観化 された経験的知識に集約される映像の再現性に由来する地位である。第二の象徵的なレヴ エルとは、意味作用のレヴェルであり、画面全体を複数の象徴表現が遂行されている記号 学的統一体と見做す映像の象徵的意味作用に由来する地位である。

しかし、われわれの視覚に対する映像の地位に関してより重要なことは、次の二点に存 する。即ち、キャメラの「非中枢性」と、フィルムの「記録性」である。つまり、キャメ ラはその機構の内部に中枢神経系の器官を持たないが故にその視覚に写る対象を分け隔て なく平等に受け止め、フィルムはそれらの対象が放つ反射光を視覚的情報として分節的体 系に回付することなく自らの上に即自的に焼き付けるということ。従って、その装置とし ての絶対的な肯定性及び受動性の結果得られた表象としての映像は、単なる対象の視覚的 再現像であるのではなく、われわれの視覚活動におけるノエシス的局面の純粋結晶として、 被写体の実在性を、われわれ自身の主観的な判断を仰ぐまでもなく、光の証拠という形で 証明しているということである。映像が以上のような特質を本性的に備えているのならば、 映像に対するわれわれの知覚的転移という現象は、一般的に言われるように、現実的な状 況から恰も夢の中に入るかの如く虚構の世界へと移行する忘我的行為であると言うより は、寧ろわれわれ人間の幻の如き不確実な視覚的世界の中で映像を通じて現実世界それ自 体の客観的且つ即自的な物質的痕跡の現実性に触れるある種の覚醒の契機であると言い得 るのである。但し、映像はあくまで「表象」として現実の事物の視覚的な再現像である限 りで、現時点においては不在のものを現前化し、現前化されているものは実質的には不在 であるという、「不在の現前化」・「現前する不在」という表象様態を成している以上、 容易に主体の知覚的転移を許さないであろう。

そこで、われわれは改めて次のように問わねばならない。即ち、われわれの映像体験が、 映像という表象を通して、被写体の物質的痕跡の現実性に触れることだとして、何故それ 
がわれわれの知覚的転移を誘発することになるのか、われわれの無意識はその痕跡の現実 性に何を見ているのか、その際知覚的転移のプロセスはどのように遂行されるのか、と。

\section{3. 映像の「まなざし」について}

このような疑問に対して、われわれは、バルトが紹介するある映画上映に関するエピソ ードに注目したい。それは次の様なものである。「古い実験によると、アフリカの叢林地 帯の原住民に初めて映画を見せた所、彼らはそこに映し出された光景（彼らの村の中央広 場）は全然見ずに、スクリーンの隅の方で、広場を横切る雌䳕だけに注目したという。」 [Barthes 1982:訳 199]このエピソードの詳細は以下のような次第である。1940年頃、映画 の教訓的効果を検証しようとしたイギリスのキリスト教宣教団が、南アフリカの黒人原住 民を教化することを目的として、とりわけ信徒の心掛けを身に付けるのに適当だと思われ るフィルムを選んで上映した。その上映後宣教師団の面々が、上映した映画の効果を確認 するために、原住民にその映画の感想を尋ねたところ、原住民は揃って、一羽の白い鶏に 心引かれたという、キリスト教徒たちにとっては思いがけない返答をした。それというの も、その映画を熟知しているはずの当のキリスト教徒たちは、そんな鵎は一度も見た覚え がなかったからである、というものである[Bazin 1953:訳 140]。それではこのエピソード は、映画におけるリアリティに関して何を語っているのであろうか。それは、観客が属し ている社会的コンテクストが異なれば、そこに不可避的にイデオロギー性が介入し、従っ てテクストの読解作業がコンテクスト・フリーではあり得ないという多文化主義的な視座 の必要性を指摘する傍証として紹介されているのであろうか。あるいは、雌觅だけに目を 奪われる原住民の野蛮な未開性を物語ることの中に垣間見える優越意識を、このエピソー ドを紹介することによって告発しているのであろうか。そうではない。何故ならば、先ほ どの文章の直後に次の一文が続くからである。「雌䳕の方が彼らに注目した、といっても いいだろう。」[Barthes 1982:訳 199] というのがそれである。つまり、バルトがこのエピ ソードを通して語っていることは、映画の画面に見入るという行為を遂行しているときに 起こっている現象の実質なのである。それは、映画の画面に惹き付けられているとき、そ の画面を見ている視線の主体が眼にしているのは、映像に表象されている対象であるとい うよりも、寧ろ映像それ自体に内在する「まなざし」なのであり、その際視線の主体は自 分の意思とは逆に、画面から見られる視線の客体になっているという、主体の能動性と受 動性の反転現象である。つまり、バルトは、われわれの映像に対する知覚的転移の由来を、 われわれが映像それ自身に内在する「まなざし」を見ること、あるいはその「まなざし」 によって見られることに見出していたのである。

それでは、その「まなざし」の実質とは一体どのようなものであるのか。バルトによる ならば、それは、「映像の起源にあるものの現実性」と写真の「事実確認能力」[Barthes 1980:訳 95]との融合、即ち写真の被写体が《かつて・どこかに確実に実在していた》と いう現実性と、われわれがプリントとして見る写真の映像が、ネガ・フィルムという形で 書き換え不可能な表象として《いま・ここに確実に記録されている》という映像自体の真 実性とが結合することによって形成される、われわれをまともに見据える能力である。

しかし、ここに一つの疑問が生じる。それは、映像に対するわれわれの知覚的転移を促 す力の由来が、映像自身が持つ「まなざし」にあるとしても、何故その「まなざし」は、 
われわれを繰り返し映像体験へと導く動因となり得るのか、ということである。こうした 疑問が生じるのは、先述したように、われわれの視覚にとって映像の「まなざし」が、例 え被写体（世界それ自体）の現実性と表象それ自体の真実性を保証する超越的な審級に位 置するとしても、その一方で、そうした属性によって、それを見るわれわれ主体の視覚的 世界の現実性が無根拠な実体に他ならないということを露呈させる、従ってわれわれ主体 の経験的自己同一性を解体する審級にもまた位置しているからである。それでは、このよ うな疑問に対して、バルト自身はどのような理論的説明をしたのであろうか。われわれは、 バルトの探求の軌跡を辿り直すことを通して、以上の疑問に応えようと思う。

まずバルトは、その晚年に独自の写真論を展開した書物である『明るい部屋」において、 写真が持つ内在的属性を、「ストゥディウム(studium)」と「プンクトゥム(punctum)」とい う対概念によって説明する。ストゥディウムとは、個人的でもあり文化的でもある気楽な 欲望と種々雑多な興味を含む一般的な関心の対象となる写真の視覚情報的側面のことであ る[ibid.:38]。従って、ストゥディウムを受容するということは、社会的・映像的な象徴的 コードに則って送り手のメッセージを読解するという視線の約束事の内部で遂行される映 像体験を意味している。一方のプンクトゥムとは、刺し傷・鋭く尖った道具によってつけ られた傷痕・小さな裂け目等の意味を表し、基本的には写真のストゥディウム的側面を破 壊-分断しにやってくる写真に内在する攻撃的な側面のことである[ibid.:39]。つまり、プン クトゥムとは、写真のうちにあって、それを見る者を突き刺すばかりか、その者に疬をつ け、その胸を締め付けにやって来るような写真の持つ見る者の自我に不快を齊す要素を指 し示しているのである。但し、プンクトゥムは、その実例を挙げていくと、ある意味でわ れわれ自身をそれに引き渡すことになるような対象としても捉えられている[ibid.:58]。言 い換えるならば、それは、われわれの視覚的欲望の対象に他ならないということである。 つまり、プンクトゥムとは、われわれの最もヴァルネラブルな部分を刺激する写真の外傷 的な性格であると言える。以上のことからバルトは、写真がわれわれを惹き付ける力の由 来をプンクトゥムに見出し、様々な写真の細部に注目しつつ、写真におけるプンクトゥム の在り方を例証していくのである。その帰結として、プンクトゥムの特性を、見る者の無 意志的記憶によって心的装置に保存されている潜在的状態にある特定の記憶痕跡を触発す ることに見出し、それは意識への内省によってのみ発見されるような性質のものなのだと 結論付けた[ibid.:67]。

しかし、バルトは、そのような地点から、「自分の快楽が不完全な媒介であるというこ と、快楽主義的な企図に還元された主観性は普遍的なものを認識しえないということ」 [ibid.:72]を宣言した上で、バルト自身にとって唯一「正しい」写真について考察するとい う、ラディカルな逆説性に基づくアプローチへと転回するのである。そのアプローチとは、 バルト自身の亡くなった母親を写した多くの写真の中の一枚、ガラス張りの天井をした温 室の中の小さな橋のたもとに、五歳になる母親と七歳になるその兄が正面を向いて並んで 立っている写真、「温室の写真」と名付けられている写真を、写真の本性を考察するため の唯一確かな拠り所として設定した上で、改めて写真がバルト自身を惹き付ける力の由来 を探求するというものであった[ibid.:88]。その探求の結果として、バルトが見出したもの こそ、先述した写真の「まなざし」に他ならない。

つまり、バルトの理論的転回の核心は、写真に若き付けられるわれわれの視覚における 
無意識の欲望の次元を照らし出すと同時に、その視覚的無意識を開示する写真の本性を、 プンクトゥムから「まなざし」へと転回したことにある。写真におけるプンクトゥム的細 部の発見は、それがわれわれの視覚的欲望を触発し発動させる作動因でもあり目的（目標） でもあるという視座を齊したのは事実であるが、そのような視座に依拠しながらも、われ われとプンクトゥム的細部との関係は、対称的な二者関係的構造に基づく自己省察に帰着 する他ないのである。何故ならば、プンクトゥムとは、われわれの心的装置のどこかに書 き込まれている記憶痕跡との類似性（投影的同一性）に基づく代用物、即ち視覚的隐喻に 他ならないからである[ibid.:66]。それに対して、写真における「まなざし」の発見は、バ ルト自身にとってのみ普遍的な価值を持つ「温室の写真」と名付けられた一枚の写真が、 決して一般化し得ない彼自身の欲望と一致することの由来を探求することによって導き出 された写真の本性であった。それでは、何故写真の「まなざし」は、バルトの知覚的転移 を誘発し得たのであろうか。言い換えるならば、何故「温室の写真」は、それを見ること が不可避的に母親の猙失という悲痛な経験の記憶へと帰着するにも拘らず、生前の母親の 実体をバルトに完全な形で㖪らせるばかりでなく、母親の死を悼むバルト自身の喪の悲し みとも合致し、尚且つバルト自身にとっての亦の作業ともなり得たのかということ。その 写真に惹き付けられる際に正確にはどのようなプロセスが展開されているのかというこ と。その写真が喚起する「憐れみ」[ibid.:142]の感情とはいかなるものであり、その感情 の由来は何処に存するのかということ、である。われわれは、以上の疑問に応えることを 通して、映像の「まなざし」を見るとき、あるいはそれに見られるときに知覚的転移とい う現象が発生するとして、その時われわれの無意識の欲望は「まなざし」の中に一体何を 求めているのか、という映像におけるリアリティの由来を明らかにしたい。

\section{4.「反復強迫」と「対象a」}

われわれは以上のような問いを探求する前に、これからの考察にとって言わば導きの系 となる、フロイトによる「反復強迫」という審級を示す一つの事例に対するラカンの解釈 を概観しておく。それは、「フォルト/ダーの遊び」[Freud 1920:訳 155-157]と呼ばれてい る一つの事例の解釈である。「フォルト/ダーの遊び」とは、フロイトの一歳半になる孫 が彼の母親の不在時に繰り返していた糸巻き遊びのことを指し、「フォルト」は、遠ざか りや消失を表わすドイツ語であり、「ダー」は、その逆の現存を意味している。その子は、 母親から愛され彼女にとてもなついていたが、母親が外出して一人部屋の中に取り残され たとき、母親を慕って泣いたりはしないで、系巻きに巻き付けられた紐を片手に握り締め、 もう一方の手でその系巻きを自分の摇り䉡の方に投げ込んでは「オー(フォルト)」とい う声を発し、次にその系巻きを器用に自分の方に手繰り寄せては「ダー」という声を発す るという遊びを繰り返すのであった。それを見たフロイトは、その子の系巻き遊びが、母 親との一時の別離を再演している行為であると解釈した。つまり、系巻きを放り投げた際 の「オー」という発語は母親の消去を、系巻きを引き寄せる際の「ダー」という発語はそ の出現を表しているのだと。しかし、フロイトは、そこで次の様な疑問を抱かざるを得な かった。何故そのような系巻き遊びを繰り返すことが、その遊びが母親との別離を意味す る限りにおいて、その子にとって直接快感と結び付くわけでもなく、寧乃自我にとって不 快な出来事の再現となっているにも拘らず、執拗に再演されるのか、その繰り返される糸 
巻き遊びにおいて、何が反復されているのか、と。ここに至ってフロイトは、その遊びの 中に示されている子供にとっての快感原則では説明できないある宿命的な力の存在に直面 し、別の審級を構想することを迫られることになる。その快感原則を越える審級にフロイ トが与えた名が「反復強迫」である。しかし、フロイトの先の解釈から推論すると、系巻 き遊びを繰り返す子供は母親の存在を系巻きによって象徽化しているのであって、従って その系巻きを使って繰り返される不快な場面の再演は、不快な体験を遊びという気楽な形 で再現して、子供がそれに耐えて自身の欲動の満足を断念できるようにするための契機を 提供していたということになるのではないか、という解釈が成立する[新宮 1995:162]。こ のような推論に対して、ラカンは別の解釈を施すのである。

ラカンの解釈の核心は、「フォルト／ダー」の遊びにおける象徴化の作業は、子供の母 親が系巻きという象徴によって置き換えられたということを指しているのではなく、それ は、母親と子供という一つの関係が、子供と系巻きというもう一つの関係によって、象徵 化されたということを指している、ということにある[Lacan 1973:62]。つまり、単に一つ の対象がある象徵によって置き換えられたのではなく、ある関係が別の関係によって置き 換えられているのである[新宮 1995:167]。ラカンの解釈によるならば、系巻きは象徴的に 置き換えられた母親であるのではなく、子供自身に他ならないのであり、その際系巻きを 手にしている当の自分は他ならぬ母親になっているということである。この象徴的な置き 換えは以下のようなプロセスによって遂行されるとされている。但し、そのプロセスが遂 行される前提として、そもそもの初めに子供は母親の愛情に包まれて在ったということと、 系巻きは母親の仕事に関係するものであり、それ故にそれは母親がよく手にしていたもの であって、子供にとってそれは母親の存在と強固に結び付いた切り離し得ない対象であっ たということがある。さて、その系巻きを、母親が外出中で不在の折に自分の手の中に持 っている子供は、その時どのような位置に置かれているのであろうか。その位置とは、仕 事の都合でよく系巻きを手にしていた母親の位置に他ならない。そして、「フォルト／ダ 一」の遊びによって放り投げられた糸巻きは、母親の傍から切り離されてしまった子供の 地位を担い、次いで自分の方に手繰り寄せられる系巻きは、母親によって抱き寄せられる 子供の地位を担っているのである。つまり、子供が「フォルト/ダー」の遊びによって系 巻きを放り投げては手繰り寄せるという行為を執拗に繰り返すのは、系巻きを手にした自 分が母親の位置に立つことによって、系巻きと化した自分自身を投げては引き寄せるとい う行為を通じて、自分が母親によって欲望されている存在であるということを何度も確認 するために他ならない[ibid.:149-158]。

ラカンはこのような子供の根源的受動性を体現すると同時に、彼の無意識の欲望（母親 の欲望の対象となること）を支える根拠の台座となる系巻きに、「対象a」という名を与 えている[Lacan 1973:62]。つまり、対象 a とは、母親の外出によって一人置き去りにされ た奇る辺ない状態にある子供が、自分は遺棄されたのではなく、欲望されているのだとい うことを自分で確認するために、その運命を握っている存在としての母親の座に立って、 自らの欲望を疑い得ない確かなものにしようとするときに必要とされる、無力な状態にあ る自分自身の地位を託されたものである。従って、対象 a とは、欲望の象徵化のための換 喻的な媒介物であると言い得る。われわれが見てきた母親の欲望の対象たらんとして糸巻 き遊びを繰り返すフロイトの孫に限らず、自分自身を他者によって欲望されていたものと 
して、即ち存在すべき必然性を持ったものとして思い描こうとする者は、その際必ずその ような存在の「必然性を掌握する者」[新宮 1995:288]の視点から見られた自分自身の寄る 辺なき姿を託された対象 a を必要とするのである。逆に言うならば、ある対象の中に根源 的な寄る辺なさが見出されるとき、人はそこに対象 aを触知しているのであり、その際人 はその対象の中に普遍的な視点から見られた自分自身の姿を見ているのである[ibid.:97]。

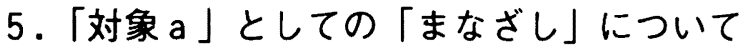

ラカンは、このようなわれわれの無意識の欲望にとって換喻的象徵の地位にある対象 a の代表的形式の一つとして「まなざし」を挙げ、その対象 a としての「まなざし」の無意 識の欲望における審級を説明するために、ハンス・ホルバインの「大使たち」と題された 絵画をその分析の対象として選んでいる[ibid.:86]。われわれは以下にラカンの洞察の核心 を検討していくが、その前に確認しておかなければならないことがある。それは、対象 a を換喻的な媒介とする欲望の象徽化のプロセスには、「疎外の演算(vel)」が組み込まれて いるということである[ibid.:210]。その「疎外の演算」を、引き続き「フォルト／ダー」 の遊びを例にして見てみる。母親から切り離されて奇る辺ない状態に置かれている子供は、 母親からの自分への欲望を実現するために、一方では母親の存在と切り離せない系巻きを 手にすることによって自分の欲望の運命を掌握する不在の母親の位置へと移行しつつ、他 方ではそこに居れば母親の欲望を身に受けることができるような構造的な位置にある対象 a としての系巻きに寄る边なき自分自身の存在を託し、それを一旦放り投げ消し去らなけ ればならない。つまり、系巻きという対象 aに仮託して自分自身の欲望（母親の欲望の対 象となること）を実現した子供は、既に母親になってしまっている、という疎外の構造が、 ラカンの言う「疎外の演算」である。このような象徵化による母親の欲望の導入が問題と なるのは、それが、系巻きという象徵によって示されている奇る辺なき状態の自分と、今 や母親の座に立ってしまっている自分とに、子供の自我が分裂してしまうからである。つ まり、欲望する者と欲望される者とがいずれも子供自身に他ならない限りで、子供自身の 欲望を実現する審級であるはずの欲望する母親が当の子供自身に他ならず、従って自分は 疑いなく欲望されているのだという確信を支える根拠を自分自身に求めていることにな り、子供の中に必然的に自己言及の困難を発生させるからである。こうして自我の内部に 自己言及の困難を抱え込んだ子供は、自分が欲望されているということを繰り返し象徵化 し続けるために、系巻き遊びを執拗に反復するか、あるいは母親の欲望を自らの内部に導 入することを助けるような新たな対象 a を次から次へと捜し求めることになる。

以上のことを確認した上で、改めてラカンが「大使たち」の画面の中に見出した対象 a としての「まなざし」の在り方を検討していく[Lacan 1973:85-114]。ホルバインの「大使 たち」は、一見これ見よがしな服飾に身を固めて不動の姿勢をとっている二人の人物が、 空しさの象徴を表わす一連のオブジェを間に挟んで立っている、取り立てて寓意的な読解 から逸脱するようなタブローであるようには見えない。しかし、そのタブローの中、二人 の人物の足元の前景に、このタブロー内の光景を無化してしまうような別の視線を導入す る、斜めに歪み宙吊りにされた奇妙な物体が描き込まれているのである。不動の姿勢をと る二人の人物と一連のオブジェが配置されている表象空間とは論理的に次元の異なる表象 系列に属するその歪像は、画面に対して斜交いの位置に立つ視線に向けて構成されている 
のであり、従ってこの歪像の存在によって、観客の視線は二重化されることになる。つま り、この歪像を見ると他の画面を見ることができず、他の画面を見ているときは、この歪 像が盲点のように視界から消え去ってしまい、観客は二つの次元の異なる表象系列を同時 に見ることはできないのである[岡崎 1995:258]。ここに視覚における無意識の次元が開示 されているのであるが、ラカンは、そのホルバインの「大使たち」に歪像として描き込ま れた髑髏こそ、対象 a としての「まなざし」に他ならないと言うのである。

ラカンによるならば、われわれの視覚的イメージの表象空間は、表象する主体を頂点と し表象される対象を底辺とした視覚のピラミッドだけから成っているのではなく、表象さ れる客体を頂点とし表象する主体を底辺としたもう一つの視覚のピラミッドが、先程のピ ラミッドを反転させた形で相互に重なり合うことで構成されている。ラカンは、後者の視 覚のピラミッドの頂点を成しているのが、「大使たち」に描き込まれた髑髏であり、その 髑髏が対象 a としての「まなざし」の審級を体現していると言うのである[ibid.:106]。つ まり、観客はあくまでも表象の主体として画面を見ていると思っているが、見ているのは 対象 $\mathrm{a}$ としての髑髅の方なのであり、観客の方こそが髑髏からの「まなざし」によって見 られているのであって、その見られるという経験において観客の無意識の欲望が照らし出 されているということである。言い換えるならば、観客は、「フォルト/ダー」の遊びに おける子供が系巻きに欲望の対象たる母親の姿を直接見ていたわけではないのと同様に、 髑髏の中に自身の欲望の対象そのものを見ているわけではないのである。観客は、対象 a として観客に見出されるのを画面の中で待っている髑髏から「まなざし」を送られている のであり、対象aはそのようにして「まなざし」を送ることによって、観客の欲望を導入 し、自らを欲望された対象として設立せんとしているのである。つまり、系巻き遊びをす る子供にとって系巻きが母親の欲望を身に受けようとする子供自身であったように、対象 a としての髑髏とは、観客自身に他ならないのである。それでは、髑髏という表象に賭け られている観客の欲望とは、いかなるものであるのか。それは、髑髏に託された死という われわれ人間の不可避の運命、即ち生の軌跡そのものが、望まれたものであったのかどう か、それが必然性を持ったものとして構成できるか否かということを、われわれは自分自 身では客観的に判断し得ないために、系巻き遊びをする子供にとっての母親の座に当たる、 タブローの表象空間の外部からその運命を見届ける存在としての観客の位置から髑髏をじ っと見つめることによって、自らを欲望の対象として設立せんということである。つまり、 自己の外部の普遍的な視点から見て、死に向かって生きているわれわれの存在とは何であ るのかということが、髑髏からの「まなざし」によって問われていることなのである。

\section{6.「温室の写真」/結びにかえて}

以上に見てきた、ラカンによる主体の無意識の欲望と対象 $\mathrm{a}$ との関係を参照することに よって、われわれは先に提起していた問い、即ち何故「温室の写真」は、快感原則を越え て、バルトの知覚的転移を誘発し得たのか、という問いに対して、次の様に応えることが できる。まず、そもそもの前提として、母親はバルトを愛し、バルトも母親を愛してやま なかったということ、「温室の写真」はすべての写真という表象形式がそうであるように、 被写体の過去の実在性を光の物質的痕跡としてフィルムに刻印しているため、母親の存在 と切り離し得ないばかりでなく、母親の実在性こそ寧万写真に記録されることで初めてそ 
の疑い得ない現実性を獲得し得るのだということがある。さて、母親を失ったばかりで裚 の悲しみに暮れているバルトは、われわれが見てきた母親に置き去りにされた子供と同様 の位置に在る。そのバルトが「温室の写真」をじっと見つめているとき、彼が置かれてい る位置は、かつて五歳の時に温室の中で兄と伴に写真を撮られた記憶を持っている母親の 座に他ならず、その際見つめられている写真の中の五歳の母親は、母親を失ったバルト自 身に他ならない。つまり、母親とバルトという一つの関係が、バルトと「温室の写真」の 中の五歳の母親というもう一つの関係によって、象徴化されているのである。次に、系巻 き遊びをする子供が系巻きを放り投げては手繰り寄せるという行為を繰り返すことで、自 分は母親から欲望されているのだということを何度も確認していたように、バルトは写真 を折に触れ見つめることで、自分は母親から欲望されていたということを確認する作業を 遂行しているのである。何故ならば、写真は被写体の「不在の現前」.「現前する不在」 という表象様態を成しているが故に、子供にとっての系巻きの消去と再現に相当するから である。こうした捉え方が毫強でない所以は、バルトが次の様な述懐を記していることに ある。バルトは、その人生の終わりにさしかかり日増しに衰弱していく母親を看病してい るうちに、いっしか彼にとって母親が「温室の写真」の中の幼い少女に戻ったように感じ られ、母親に対してまるで自分の娘に接しているかのように向き合う自分を発見する。そ の関係は恰も自分が「母の病気を通して母を子供として生みだした」に等しいものであっ た[Barthes 1980:訳 87]。以上がその内容である。従って、バルトの欲望とは、自分自身を 何とか母親から望まれた存在として設立しよjとするものであったと言い得るのである。

その欲望を実現するプロセスは、以下の通りである。バルトはある日亡くしたばかりの 母親の真実の姿が写し出されている写真を探し求めていたところ、多くの写真の中から 「温室の写真」の中の五歳になる母親を発見する。但し、バルトは見る主体として写真を 発見したのではなく、写真の中の少女に見られていたのである。その少女こそ対象aに他 ならない。つまり、その対象aとしての少女は、一方で「まなざし」を送ることによって、 自分が見出されるのを無意識の中で待っているバルト自身の地位を担い、他方でバルトの 地位を担うことで彼が母親の位置に移行することを助けるような構造的位置を占めている のである。対象 aのそのような換喻的機能によって自身の運命を握る母親の位置に立った バルトは、自分に送られてくる「まなざし」を受け止め、逆にそれをじっと見つめ返すこ とによって欲望を実現させるのである。それでは何故多くの写真の中の特に「温室の写真」 が、バルトの知覚的転移を誘発したのか。その理由は知る由もないが、一つには、その写 真が母親の不仲だった両親が離婚する直前に、それ故に却って仲の良かった兄と伴に撮影 されたものであるということが挙げられるかもしれない[ibid.:82]。つまり、恰もホルバイ ンの「大使たち」の画面を構成する様々な表象の中から、われわれの運命を託された髑髏 がわれわれに見出されるために「まなざし」を送っていたように、母親の心的装置におけ る無意識の平面に書き込まれ並列的にストックされている様々な記憶痕跡の中から、何ら かの決定的な喪失が訪れる直前の記憶と重なるであろう「温室の写真」が、バルトに見出 されるために「まなざし」を送っていたのではないか。そうした母親の事情を知っている バルトは、母親を失ったばかりの部屋で韍の悲しみに包まれていたが、ある時「温室の写 真」の「まなざし」を発見し、先に説明した通り母親の位置に移行しつつ、送られた「ま なざじ」をじっと見つめることによって、母親から切り離されたバルトの地位を託された 
少女の欲望、即ち母親からの欲望を身に受けるという自身の欲望を実現したのではない か。

以上の考察からわれわれは、映像におけるリアリティの由来とは、われわれの欲望を換 喻的に実現する、対象 a としての「まなざし」に他ならないと言うことができる。そして、 われわれが対象 a としての「まなざし」に注目するのは、われわれと世界とを慗ぐ紏が稀 薄になり、われわれが自らの存在について何の確証も見出せないような状況に立たされた 時、それが、われわれの内省によっては到達し得ない現実性に触れる契機を提供し、われ われが自らの存在の必然性を束の間感じ取るための触媒になり得るからである。

\section{参考文献}

Barthes,R., 1980，La chambre claire,Gallimard,Seuil.花輪充(訳),『明るい部屋』，みすず書房, 1985 1983, L'obvie et L'obtus,Édition du Seuil.沢崎浩平(訳),「眼の中をじっと」『美術論集』,みすず 書房, 1986

Bazin,A., 1953,Le Langage de notre temps,西嶋憲生(訳),「現代の言語」『映画理論集成』フィルムアート 社, 1982

Benveniste,E., 1966, Problèmes de linguistique générale, Éditions Gallimard.河村正夫 ·岸本通夫 ·木下光 一・高塚洋太郎・花輪光・矢島猷三（共訳）, 『一般言語学の諸問題』，みすず書房 1983

Freud,S., 1920, Jenseits des Lustprinzips.小此木啓吾(訳), 「快感原則の彼岸」「フロイト著作集 6 」, 人文書 院1968

石光康夫 1995 『身体 光と闇』未来社

Kant,I., 1787, Kritik der reinen Vernunft.篠田英雄(訳),『純粋理性批判』,岩波文庫 1961

木村敏 1988 『あいだ』弘文堂

小林康夫 1995 『身体と空間』筑摩書房

Krauss,R., 1988. The Im/pulse to See, in Hal Foster(ed.),Vision and Visuality, Bay Press.

1993, Optical Unconscious,MIT Press.

Lacan,J., 1973, The Four Fundamental Concepts of Psycho-Analysis,tran.Sheridan,A., Norton \&Company,1981. 前田英樹 1996 『イマージュの秘蹟』青土社

McLuhan,M., 1964, Understanding Media, McGraw-Hill Book Company.栗原裕・河本仲聖(訳),『メディア 論』,みすず書房 1987

Merleau-Ponty,M., 1945, La Phénoménologie de la Perception,Édition Gallimard.竹内芳郎・木田元·宮本 忠雄訳, 『知覚の現象学』,みすず書房 1974

Metz,C., 1972, Essais sur la signification au cinéma tome 2,Éditions Klincksieck.浅沼圭司監(訳), 『映画記 号学の諸問題』,水声社 1987

松浦寿輝 1994 『平面論』岩波書店

岡崎乾二郎 1995 「経験の条件」、『批評空間』臨時增刊号:246-261.福武書店

新宮一成 1989 『無意識の病理学」金剛出版

—1995『ラカンの精神分析』講談社現代新書

1997 『無意識の組曲』岩波書店

Wittgenstein,L., 1961,Tractatus Logico-Philosophicus, Routledge \& Kegan Paul Ltd..奥雅博(訳),「論理的学 論考」『ウイトゲンジ多价全集 1」,大修館書店 1975 